\title{
Implementasi Teams Games Tournaments dan Number Head Together ditinjau dari Kemampuan Penalaran Matematis
}

\author{
Nurina Kurniasari Rahmawati \\ STKIP Kusuma Negara: Nurinakr@gmail.com
}

\begin{abstract}
The purpose of this study was to determine the effect of Teams Games Tournaments (TGT) and Numbered Head Together (NHT) learning models on mathematics achievement that reviewed students' mathematical reasoning abilities. The research method applied is experimental research. The type of research used is quasi experiment research. The research design used a $3 \times 3$ factorial design. The research sample was taken using cluster random sampling technique. Data collection used is using two types, namely documentation and tests. The instrument used for data collection consists of tests of mathematical reasoning abilities and tests measuring the ability of students' learning achievement. The test of mathematical reasoning ability is in the form of multiple choice test questions, while learning achievement tests are in the form of objective test questions that contain the sequence and series material according to the indicators measured. Hypothesis testing used is a parametric test with data analysis techniques using the Anova test. The results of the prerequisite test were carried out based on the normality test which can be known by using the Liliefors test and the homogeneity test can be known by using the Barlett test. two paths with cells are not the same. The results of this research review, namely there is the effect of TGT and NHT learning models on students' mathematical reasoning abilities; Mathematical achievement with the TGT model is better than mathematics achievement with NHT learning models and Conventional learning; and students with high mathematical reasoning abilities have better learning achievement compared to moderate and low mathematical reasoning abilities.
\end{abstract}

Keywords: TGT \& NHT, Mathematics Reasoning, Mathematics Achievement

\begin{abstract}
Abstrak
Tujuan penelitian ini untuk mengetahui pengaruh model pembelajaran Teams Games Tournaments (TGT) dan Numbered Head Together (NHT) terhadap prestasi matematika yang meninjau terhadap kemampuan penalaran matematis siswa. Metode penelitian yang diterapkan adalah penelitian eksperimen. Jenis penelitian yang digunakan adalah penelitian quasi experiment. Desain penelitian dengan menggunakan rancangan desain faktorial $3 \times 3$. Pengambilan sampel penelitian menggunakan teknik cluster random sampling. Pengumpulan data yang digunakan adalah menggunakan dua macam yaitu dokumentasi dan tes. Instrumen yang digunakan untuk pengambilan data terdiri atas tes kemampuan penalaran matematis dan tes mengukur kemampuan prestasi belajar siswa. Tes kemampuan penalaran matematis berupa soal tes yang berbentuk pilihan ganda, sedangkan tes prestasi belajar berbentuk soal tes objektif yang berisi materi barisan dan deret sesuai indikator-indikator yang diukur. Uji hipotesis yang digunakan merupakan uji parametris dengan teknik analisis data menggunakan uji Anova. Hasil penelitian untuk uji prasyarat dilakukan berdasarkan uji normalitas yang dapat diketahui dengan menggunakan uji Liliefors dan uji homogenitas dapat diketahui dengan mengggunakan uji Barlett, diperoleh bahwa data hasil tes dari kedua kelompok tersebut adalah normal
\end{abstract}


dan homogen, sehingga dapat dilanjutkan untuk uji parametris dengan menggunakan uji anava dua jalan dengan sel tak sama. Adapun hasil tinjauan penelitian ini, yaitu terdapat pengaruh model pembelajaran TGT dan NHT terhadap kemampuan penalaran matematis siswa; prestasi matematika dengan model TGT lebih baik dibandingkan prestasi matematika dengan model pembelajaran NHT dan pembelajaran Konvensional; dan siswa dengan kemampuan penalaran matematis tinggi memiliki prestasi belajar yang lebih baik dibandingkan dengan kemampuan penalaran matematis sedang dan rendah.

Kata Kunci: Model TGT dan NHT, Kemampuan Penalaran Matematis, Prestasi Matematika

\section{PENDAHULUAN}

Pendidikan merupakan hal yang penting, wajib ditempuh mulai dari pendidikan dasar hingga sekolah menegah, bahkan sampai pada tingkat perguruan tinggi. Hal ini dikarenakan dalam pendidikan terjadi proses belajar yang dapat memungkinkan seseorang untuk mengembangkan kemampuannya secara optimal (Lanani, 2015; Mikrayanti, 2016). Kemampuan seseorang dapat berkembang dengan adanya proses belajar, salah satunya adalah dalam pembelajaran matematika. Matematika itu sendiri memiliki peranan yang sangat penting dalam kehidupan (Wibowo, 2017). Pentingnya matematika untuk di pelajari mulai dari jenjang sekolah dasar hingga perguruan tinggi (Widiastuti, 2014; Alifiani, 2017). Salah satu tujuan pembelajaran matematika adalah meningkatkan kemampuan penalaran matematis siswa (R. Triastuti, 2013). Pembelajaran matematika di sekolah yang seharusnya dapat menyiapkan siswa untuk memiliki kemampuan penalaran matematis sebagai bekal untuk menghadapi tantangan perkembangan dan perubahan. Mempelajari matematika membutuhkan kemampuan pemahaman bernalar yang baik, karena matematika hanya dapat dipahami dengan cara bernalar (Hapizah, 2014; Rosita, 2014; Lanani, 2015; Boxtel, 2016; Ridwan, 2017). Sebagaimana dalam dediknas menyatakan, bahwa materi matematika dan penalaran matematis merupakan dua hal yang sangat terkait dan tidak dapat dipisahkan, karena materi matematika dipahami melalui penalaran dan penalaran dipahami dan dilatihkan melalui belajar matematika (Zaenab, 2016; Mikrayanti, 2016). Selain itu juga kemampuan bernalar dibutuhkan dalam memecahkan masalah kehidupan sehari-hari (Sutoyo, 2015; Ridwan, 2017). Oleh karena itu diharapkan dalam suatu proses belajar tersebut dapat menghasilkan sebuah prestasi, terutama pada mata pelajaran matematika. Pestasi yang dimaksud berupa pencapaian hasil belajar dengan ditandai adanya perubahan konstruksi pemikiran dari diri seseorang yang merupakan evaluasi akhir dari kegiatan belajar (Trisnawati, 2015; Setiawan, 2017). Namun pada kenyataannya prestasi yang dihasilkan belum sesuai dengan yang diharapkan, siswa merasa kesulitan dan masih rendahnya hasil belajar siswa (Siregar, 2012). Rendahnya hasil belajar dan kesulitan dalam belajar matematika tersebut, salah satunya disebabkan oleh kurangnya peran guru untuk lebih memperhatikan penggunaan model pembelajaran yang diterapkan dalam pembelajaran. Kurang tepat dan efektifnya penerapan model yang digunakan, maka dalam hal ini membutuhkan solusi yang tepat untuk mengatasi masalah tersebut, sebagai langkah perbaikan dalam pembelajaran. Langkah perbaikan dalam pembelajaran yang dapat dilakukan salah satunya adalah dengan memilih model pembelajaran 
yang tepat, yaitu model pembelajaran dengan tipe kooperatif. Banyak tipe model kooperatif yang dapat digunakan, antara lain model pembelajaran kooperatif tipe Teams Games Tournaments (TGT) dan Numbered Head Together (NHT).

Teams Games Tournaments (TGT) merupakan model pembelajaran kooperatif yang dikembangkan oleh Robert Slavin yang mudah diterapkan dengan melibatkan aktivitas seluruh siswa tanpa harus ada perbedaan status yang mengutamakan belajar berkelompok sehingga dapat meningkatkan hasil belajar siswa (Purnawan, 2015; Susmiatiningsih, 2013; Dargito, 2014; Widhiastuti, 2014; Subroto, 2015; Gusniawati S., 2015; Aryani, 2015; Lovieana, 2015; Fitrianawati, 2016; Munawaroh, 2016). Sedangkan model Numbered Head Together (NHT) merupakan model pembelajaran kooperatif yang mengutamakan belajar berkelompok dengan dirancang untuk mempengaruhi pola interaksi siswa dalam mengembangkan kemampuan siswa untuk berpikir memecahkan masalah dengan tujuan meningkatkan kemampuan akademik dan aktivitas hasil belajar siswa agar meraih keberhasilan dalam pembelajaran (Siregar, 2012; Jamalong, 2012; Hadiyanti, 2012; Khasanah, 2013; Agustina, 2015; Anggoro, 2015; Fausan, 2016; Firdaus, 2016; Prastiti, 2016; Raharja, 2016). Model pembelajaran yang dipilih diharapkan mampu mengembangkan kemampuan penalaran matematis sehingga dapat meningkatkan prestasi matematika siswa. Kemapuan penalaran matematis adalah salah satu kemampuan berpikir yang perlu dikembangkan sebagai syarat cukup untuk dapat menguasai matematika dengan kegiatan berpikir berdasarkan kondisi dan syarat yang ada dalam pengambilan keputusan untuk menghasilkan suatu pernyataan dalam mencapai kesimpulan pada waktu menyelesaikan suatu masalah (A.S. Ruslan, 2013; Handayani, 2013; Nursyahidah, 2016; Pamungkas, 2016). Dengan memiliki kemampuan dalam matematika, dapat membentuk pola pikir seseorang yang sistematis untuk dapat meningkatkan prestasi matematika siswa (Wibowo, 2017). Prestasi adalah pengetahuan, keterampilan, dan kemampuan yang telah dikembangkan siswa sebagai suatu hasil pembelajaran (Farida, 2014; Marasiwi, 2017; Setiawan, 2017; Wibowo, 2017). Prestasi yang dimaksud adalah hasil capaian belajar matematika. Jadi prestasi matematika adalah tingkat penguasaan materi dan pencapaian standar kompetensi matematika setelah siswa mengalami kegiatan belajar matematika yang diukur dengan menggunakan tes berupa seperangkat soal yang menggambarkan materi belajar dan kompetensi dasar yang harus dikuasai siswa (Rianto, 2014). Kesuksesan dalam belajar ditentukan oleh banyak faktor (Putra, 2014). Ada beberapa faktor yang dapat mempengaruhi prestasi seseorang yaitu meliputi; motivasi diri, kepercayaan diri, bakat alami, kemauan untuk tekun, kepribadian bahkan keadaan kesehatan (Rianto, 2014). Sebagaimana pendapat Sardiman, bahwa intensitas motivasi seseorang akan sangat menentukan tingkat pencapaian prestasi belajar terutama prestasi matematikannya (Hidayati, 2017). Adapun penelitian sebelumnnya yang telah menggunakan model pembelajaran kooperatif tipe TGT dan NHT diantaranya: TGT lebih efektif dibandingkan NHT terhadap motivasi dan tanggapan siswa pada mata pelajaran IPS; TGT lebih efektif dibandingkan NHT terhadap prestasi dan kepuasan pembelajaran kelistrikan otomotif; TGT dan NHT efektif ditinjau dari aspek prestasi belajar pada materi matematika dan sikap matematika siswa; TGT dan NHT efektif untuk meningkatkan motivasi 
dan pemahaman konsep materi matematika (Shoolihah, 2012; Purnawan, 2015; Suzana, 2017; Alifiani, 2017).

Berdasarkan penelitian yang sudah ada sebelumnya, dalam penelitian ini diterapkan juga model yang sama yaitu, model pembelajaran kooperatif tipe TGT dan NHT dengan keterbaruan untuk mengetahui pengaruh model pembelajaran Teams Games Tournaments (TGT) dan Numbered Head Together (NHT) terhadap prestasi matematika yang meninjau terhadap kemampuan penalaran matematis siswa.

\section{METODE PENELITIAN}

Metode penelitian yang diterapkan adalah penelitian eksperimen. Jenis penelitian yang digunakan adalah penelitian quasi experiment. Desain penelitian yang digunakan dirancang dengan desain faktorial $3 \times 3$. Pengambilan sampel penelitian menggunakan teknik cluster random sampling. Pengumpulan data yang digunakan adalah menggunakan dua macam yaitu dokumentasi dan tes. Instrumen yang digunakan untuk pengambilan data terdiri atas tes kemampuan penalaran matematis dan tes mengukur kemampuan prestasi belajar siswa. Tes kemampuan penalaran matematis berupa soal tes yang berbentuk pilihan ganda, sedangkan tes prestasi belajar berbentuk soal tes objektif yang berisi materi barisan dan deret sesuai indikator-indikator yang akan diukur. Uji prasyarat untuk uji coba normalitas menggunakan uji Lilliefors dengan taraf signifikasi $5 \%$ dengan hipotesis yang diuji adalah:

$H_{o}$ : Sebaran data berdistribusi normal

$H_{a}$ : Sebaran data berdistribusi tidak normal

Sebaran data dikatakan berdistribusi normal jika $L_{\text {hitung }}<L_{\text {tabel }}$ maka $H_{o}$ diterima, namun jika $L_{\text {hitung }} \geq L_{\text {tabel }}$ maka $H_{o}$ ditolak.

Uji prasyarat untuk uji coba homogenitas menggunakan uji Bartlett dengan taraf signifikasi 5 $\%$ dengan hipotesis yang diuji adalah:

$H_{o}$ : Sebaran data adalah homogen

$H_{a}$ : Sebaran data tidak homogen

Sebaran data dikatakan homogen jika $X^{2}{ }_{\text {hitung }} \leq X^{2}{ }_{\text {tabel }}$ maka maka $H_{o}$ diterima, namun jika $X^{2}{ }_{\text {hitung }} \geq X^{2}{ }_{\text {tabel }}$ maka $H_{o}$ ditolak.

Uji keseimbangan menggunakan anava satu jalan dengan sel tak sama, dengan uji hipotesis analisis variansi anava dua jalan dengan sel tak sama yang dilanjutkan dengan uji komparasi ganda dengan metode Scheffe jika hipotesis nol ditolak. Data hasil penelitian tersebut berupa nilai tes prestasi belajar matematika siswa. Adapun prosedur rancangan penelitian dengan desain faktorial $3 \times 3$ sebagaimana disajikan pada Tabel 1 .

Tabel 1. Rancangan Desain Faktorial $3 \times 3$

\begin{tabular}{|cccc} 
Model Pembelajaran & \multicolumn{3}{c}{ Kemampuan Prestasi Matematika Siswa } \\
\cline { 2 - 4 } & Tinggi $\left(b_{1}\right)$ & Sedang $\left(b_{2}\right)$ & Rendah $\left(b_{3}\right)$ \\
\hline Pembelajaran TGT $\left(a_{1}\right)$ \& NHT & $a b_{11}$ & $a b_{12}$ & $a b_{13}$ \\
\hline$\left(a_{2}\right)$ & $a b_{21}$ & $a b_{22}$ & $a b_{23}$ \\
\hline Pembelajaran Konvensional $\left(a_{3}\right)$ & $a b_{31}$ & $a b_{32}$ & $a b_{33}$ \\
\hline
\end{tabular}


Adapun kombinasi yang dapat dibuat dari rancangan pada Tabel 1 meliputi; $a b_{11}, a b_{12}, a b_{13}$, $a b_{21}, a b_{22}, a b_{23}, a b_{31}, a b_{32}, a b_{33}$, dimana untuk setiap kombinasi akan memiliki nilai respon eksperimen berdasarkan hasil pengamatan pada eksperimen.

\section{HASIL PENELITIAN DAN PEMBAHASAN}

Data dalam penelitian ini meliputi: data hasil uji coba instrumen, data kemampuan awal matematika, data kemampuan penalaran matematis, dan data prestasi matematika siswa pada materi barisan dan deret. Hasil uji validitas isi telah divalidasi oleh 3 orang validator menunjukkan bahwa instrumen tes kemampuan penalaran matematis dan tes prestasi matematika dikatakan valid dan reliabel.

Sebelum melakukan uji parametris terlebih dahulu dilakukan uji asumsi prasyarat diantaranya: uji normalitas dan homogenitas. Uji normalitas untuk mengetahui apakah sebaran data berdistribusi normal atau tidak dan uji homogenitas untuk mengetahui sama tidaknya variansi dua buah distribusi data. Pengujian hasil uji prasyarat dengan menggunakan uji Lilliefors dengan taraf signifikasi $5 \%$. Sebaran data dikatakan berdistribusi normal jika $L_{\text {hitung }}<L_{\text {tabel }}$ maka $H_{0}$ diterima, namun jika $L_{\text {hitung }} \geq L_{\text {tabel }}$ maka $H_{o}$ ditolak. Adapun hasil uji normalitas kemampuan penalaran matematis pada ketiga model dapat dilihat pada Tabel 2.

Tabel 2. Hasil Uji Normalitas Kemampuan Penalaran Matematis

\begin{tabular}{|ccccc}
\hline $\begin{array}{c}\text { Model } \\
\text { Pembelajaran }\end{array}$ & $\boldsymbol{L}_{\text {hitung }}$ & $\boldsymbol{L}_{\text {tabel }}$ & Keputusan Uji & Kesimpulan \\
\hline NHT & 0.074 & 0.089 & $H_{o}$ Diterima & Normal \\
\hline TGT & 0.087 & 0.089 & $H_{o}$ Diterima & Normal \\
\hline Konvensional & 0.082 & 0.089 & $H_{o}$ Diterima & Normal \\
\hline
\end{tabular}

Pada Tabel 2, diperoleh bahwa pada model NHT $L_{\text {hitung }}<L_{\text {tabel }}=0.074<0.089$, pada model TGT diperoleh $L_{\text {hitung }}<L_{\text {tabel }}=0.087<0.089$, dan pada model Konvensional diperoleh $L_{\text {hitung }}<L_{\text {tabel }}=0.082<0.089$. Dengan ketiga uji hipotesis $H_{o}$ diterima. Artinya sebaran data berdistribusi normal. Data hasil tes kemampuan penalaran matematis siswa yang diperoleh, kemudian dikategorikan ke dalam kategori kemampuan penalaran matematis tinggi, sedang, dan rendah. Pengelompokan data tersebut, dilakukan berdasarkan hasil dari uji asumsi kenormalan. Adapun hasil prestasi matematika pada masingmasing kategori model pembelajaran pada tes kemampuan penalaran matematis siswa dapat dilihat pada Tabel 3.

Tabel 3. Hasil Prestasi Matematika Siswa

\begin{tabular}{|c|cccc}
\hline Model & \multicolumn{2}{|c|}{ Kemampuan Penalaran Matematis } & Rerata Marginal \\
Pembelajaran & Tinggi & Sedang & Rendah & 68.12 \\
\hline TGT & 76.53 & 64.61 & 63.66 & 60.94 \\
\hline NHT & 89.21 & 61.17 & 58.28 & 55.71 \\
\hline Konvensional & 67.78 & 58.23 & 46.84 & \\
\hline Rerata Marginal & 69.17 & 61.12 & 55.71 & \\
\hline
\end{tabular}


Berdasarkan pada Tabel 3, dalam hal ini siswa tergolong memiliki prestasi matematika terhadap kemampuan penalaran matematis tinggi jika skor yang diperoleh lebih dari 7. Siswa tergolong memiliki prestasi matematika terhadap kemampuan penalaran matematis sedang jika skor yang diperoleh kurang dari atau sama dengan 7 dan lebih dari atau sama dengan 6 . Siswa tergolong memiliki prestasi matematika terhadap kemampuan penalaran matematis rendah jika skor yang diperoleh kurang dari 6.

Sebelum melakukan uji hipotesis, terlebih dahulu dilakukan uji prasyarat uji hipotesis berupa uji normalitas populasi dan uji homogenitas variansi populasi terhadap nilai tes prestasi matematika. Hasil uji normalitas yang dilakukan sebanyak 6 kali terhadap masingmasing model pembelajaran dan kemampuan penalaran matematis siswa, menunjukkan bahwa sampel berasal dari populasi berdistribusi normal dapat dilihat pada Tabel 4.

Tabel 4. Hasil Uji Normalitas Kemampuan Penalaran Matematis

\begin{tabular}{c|c|c|c|c|c}
\hline Model & $\boldsymbol{N}$ & $\boldsymbol{L}_{\boldsymbol{h i t u n g}}$ & $\boldsymbol{L}_{\text {tabel }}$ & Keputusan Uji & Kesimpulan \\
\hline TGT & 100 & 0.0795 & 0.0886 & $H_{O}$ Diterima & Normal \\
\hline NHT & 99 & 0.0698 & 0.089 & $H_{O}$ Diterima & Normal \\
\hline Konvensonal & 99 & 0.0748 & 0.089 & $H_{O}$ Diterima & Normal \\
\hline Penalaran Tinggi & 84 & 0.0722 & 0.0968 & $H_{O}$ Diterima & Normal \\
\hline Penalaran Sedang & 116 & 0.0772 & 0.0823 & $H_{O}$ Diterima & Normal \\
\hline Penalaran Rendah & 98 & 0.0787 & 0.089 & $H_{O}$ Diterima & Normal \\
\hline
\end{tabular}

Pada Tabel 4, diperoleh bahwa pada ke enam hasil uji normalitas terhadap kemampuan penalaran matematis diperoleh $L_{\text {hitung }}<L_{\text {tabel }}$. Dengan uji hipotesis $H_{o}$ diterima. Artinya sebaran data berdistribusi normal. Uji prasyarat untuk uji coba homogenitas menggunakan uji Bartlett dengan taraf signifikasi $5 \%$. Sebaran data dikatakan homogen jika $X^{2}{ }_{\text {hitung }} \leq$ $X^{2}{ }_{\text {tabel }}$ maka $H_{o}$ diterima, namun jika $X^{2}{ }_{\text {hitung }} \geq X^{2}{ }_{\text {tabel }}$ maka $H_{o}$ ditolak. Adapun hasil uji homogenitas dapat dilihat pada Tabel 5.

Tabel 5. Hasil Uji Homogenitas Kemampuan Penalaran Matematis

\begin{tabular}{|l|c|c|c|c|r}
\hline & $K$ & $X^{2}$ tabel & $X^{2}{ }_{\text {hitung }}$ & Keputusan Uji & Kesimpulan \\
\hline Model Pembelajaran & 3 & 0.0162 & 5.991 & $H_{o}$ Diterima & Homogen \\
\hline Kemampuan Penalaran & 3 & 4.6144 & 5.991 & $H_{o}$ Diterima & Homogen \\
\hline
\end{tabular}

Pada Tabel 5, diperoleh bahwa pada hasil uji homogenitas pada model pembelajaran dan kemampuan penalaran matematis diperoleh $X^{2}{ }_{\text {hitung }} \geq X^{2}$ tabel. Dengan uji hipotesis $H_{o}$ diterima. Artinya sebaran data berdistribusi homogen. Berdasarkan hasil uji prasyarat terpenuhi, maka pengujian hipotesis dapat dilakukan menggunakanan alisis variansi dua jalan dengan sel tak sama. Dengan taraf siginfikansi 0.05 , diperoleh hasil perhitungan analisis variansi dua jalan dengan sel tak sama dapat dilihat padaTabel 6 . 
Tabel 6. Hasil Analisis Variansi Dua Jalan dengan Sel Tak Sama

\begin{tabular}{cccccc}
\hline Sumber & $\boldsymbol{J K}$ & $\boldsymbol{d} \boldsymbol{k}$ & $\boldsymbol{R} \boldsymbol{K}$ & Fobs & $\mathbf{F} \boldsymbol{\alpha}$ \\
$\begin{array}{c}\text { Model } \\
\text { Pembelajaran }\end{array}$ & 5618.15 & 2 & 2809.07 & 12.98 & 3.00 \\
\hline $\begin{array}{c}\text { Kemampuan } \\
\text { Penalaran }\end{array}$ & 7856.33 & 2 & 3928.16 & 18.15 & 3.00 \\
\hline $\begin{array}{c}\text { Interaksi } \\
\text { Galat }\end{array}$ & 2606.30 & 4 & 651.57 & 3.01 & 2.37 \\
\hline Total & 782541.37 & 289 & 216.41 & & \\
\hline
\end{tabular}

Berdasarkan pada Tabel 6, diperoleh perhitungan $F_{o b s}$ untuk $H_{0 A}, H_{0 B}$ dan $H_{0 A B}$ yang hasilnya tampak pada Tabel 3 diperoleh keputusan uji bahwa $H_{0 A}, H_{0 B}$, dan $H_{0 A B}$ ditolak. Berdasarkan keputusan uji tersebut dapat disimpulkan bahwa: (1) model pembelajaran berpengaruh terhadap prestasi belajar, (2) kemampuan penalaran matematis berpengaruh terhadap prestasi belajar, (3) ada interaksi antara model pembelajaran dan kemampuan penalaran matematis terhadap prestasi belajar matematika. Karena $H 0 A, H 0 B$ dan $H 0 A B$ ditolak maka perlu dilakukan uji lanjut pasca anava dengan metode Scheffe' yaitu uji komparasi rataan antar baris, uji komparasi rataan antar kolom dan uji komparasi rataan antar sel. Adapun hasil uji komparasi ganda antar baris diperoleh hasil sebagaimana pada Tabel 7.

Tabel 7. Hasil Uji Komparasi Ganda Anatar Baris

\begin{tabular}{cccc}
$\boldsymbol{H}_{\boldsymbol{o}}$ & $F_{\text {obs }}$ & \multicolumn{1}{c}{$2 F_{a ; v}$} & Keputusan Uji \\
$\boldsymbol{\mu}_{\mathbf{1}}=\boldsymbol{\mu}_{\mathbf{2}}$ & 11.58 & $(2)(3.00)=6.00$ & $H_{o}$ Ditolak \\
$\boldsymbol{\mu}_{2}=\boldsymbol{\mu}_{3}$ & 35.42 & $(2)(3.00)=6.00$ & $H_{o}$ Ditolak \\
$\boldsymbol{\mu}_{\mathbf{1}}=\boldsymbol{\mu}_{\mathbf{3}}$ & 6.26 & $(2)(3.00)=6.00$ & $H_{o}$ Ditolak \\
\hline
\end{tabular}

Berdasarkan pada Tabel 7, dengan membandingkan dengan daerah kritis, terlihat bahwa terdapat perbedaan yang signifikan antara $\mu_{1}$ dengan $\mu_{2}, \mu_{2}$ dengan $\mu_{3}$, serta $\mu_{1}$ dengan $\mu_{3}$. Dengan memperhatikan rerata marginalnya, dapat disimpulkan bahwa: dapat disimpulkan bahwa: (1) Model pembelajaran TGT lebih baik dari model pembelajaran NHT, karena rerata TGT sebesar 69.12 sedangkan rerata NHT sebesar 61.94, yang artinya rerata TGT lebih besar dari rerata NHT. (2) Model pembelajaran TGT lebih baik dari model pembelajaran langsung, karena rerata TGT sebesar 69.12 sedangkan untuk hasil rerata konvensional sebesar 56.71, yang artinya rerata TGT lebih besar dari rerata konvensional. (3) Model pembelajaran NHT lebih baik dari model pembelajaran konvensonal, karena rerata NHT sebesar 61.94 sedangkan untuk hasil rerata konvensional sebesar 56.71, yang artinya rerata NHT lebih besar dari reratak onvensional. Pada uji komparasi ganda antar kolom diperoleh hasil seperti disajikan pada Tabel 8.

Tabel 8. Hasil Uji Komparasi Ganda Anatar Kolom

\begin{tabular}{cccc}
$H_{o}$ & $\boldsymbol{F}_{\text {obs }}$ & $\mathbf{2 F}_{\boldsymbol{a} ; \boldsymbol{v}}$ & Keputusan Uji \\
$\boldsymbol{\mu}_{\mathbf{1}}=\boldsymbol{\mu}_{\mathbf{2}}$ & 14.57 & $(2)(3.00)=6.00$ & $H_{o}$ Ditolak \\
\hline $\boldsymbol{\mu}_{\mathbf{2}}=\boldsymbol{\mu}_{\mathbf{3}}$ & 37.82 & $(2)(3.00)=6.00$ & $H_{o}$ Ditolak \\
$\boldsymbol{\mu}_{\mathbf{1}}=\boldsymbol{\mu}_{\mathbf{3}}$ & 7.17 & $(2)(3.00)=6.00$ & $H_{o}$ Ditolak \\
\hline
\end{tabular}


Dengan membandingkan $F_{o b s}$ dengan daerah kritis, tampak bahwa terdapat perbedaan yang signifikan antara $\mu_{.1}$ dengan $\mu_{.2}, \mu_{.2}$ dengan $\mu_{.3}$, serta $\mu_{.1}$ dengan $\mu_{.3}$. Dengan memperhatikan rerata marginal masing-masing kolom, dapat disimpulkan bahwa: (1) siswa dengan kemampuan penalaran matematis tinggi mempunyai prestasi belajar yang lebih baik dari pada siswa dengan kemampuan penalaran matematis sedang, karena rerata siswa dengan kemampuan penalaran matematis tinggi yaitu nilainya sebesar 69.17 sedangkan untuk siswa dengan kemampuan penalaran matematis sedang yaitu dengan nilai sebesar 61.12, yang artinya setelah dianalisis rerata siswa dengan kemampuan penalaran matematis tinggi lebih besar daripada penalaran matematik rerata siswa dengan kemampuan sedang, (2) siswa yang mempunyai penalaran matematis dengan kemampuan tinggi, prestasi belajarnya lebih baik dari pada siswa dengan kemampuan penalaran matematis rendah, hal ini karena nilai rerata siswa dengan kemampuan penalaran matematis tinggi sebesar 69.17. nilai siswa dengan kemampuan penalaran matematis rendah sebesar 55.71. dengan demikian, rerata siswa dengan kemampuan penalaran matematis tinggi lebih besar dari rerata siswa dengan kemampuan penalaran matematis rendah. dan (3) kemudian siswa yang memiliki penalaran matematis sedang prestasi belajarnya lebih baik dari pada siswa dengan penalaran matematis rendah, dikarenakan nilai rerata siswa dengan kemampuan penalaran matematis sedang sebesar 61.12 sedangkan nilai siswa dengan kemampuan penalaran matematis rendah sebesar 55.71. untuk itu, saya menganilisis bahwa hasil rerata siswa yang memiliki kemampuan penalaran matematis sedang lebih baik dibandingkan dengan rerata siswa yang memiliki kamampuan matematis rendah. Pada uji komparasi ganda antar sel diperoleh hasil seperti disajikan pada Tabel 9.

Tabel 9. Hasil Uji Komparasi Rataan Antar Sel

\begin{tabular}{|c|c|c|c|}
\hline$H_{o}$ & $F_{o b s}$ & $8 F_{a ; v}$ & Keputusan \\
\hline$\mu_{11}=\mu_{21}$ & 14.08 & (8) $(1.94)=15.52$ & $H_{O}$ Diterima \\
\hline$\mu_{11}=\mu_{31}$ & 4.08 & $(8)(1.94)=15.52$ & $H_{O}$ Diterima \\
\hline$\mu_{21}=\mu_{31}$ & 1.26 & $(8)(1.94)=15.52$ & $H_{O}$ Diterima \\
\hline$\mu_{12}=\mu_{22}$ & 0.99 & $(8)(1.94)=15.52$ & $H_{O}$ Diterima \\
\hline$\mu_{12}=\mu_{32}$ & 3.73 & (8) $(1.94)=15.52$ & $H_{o}$ Diterima \\
\hline$\mu_{22}=\mu_{32}$ & 0.79 & $(8)(1.94)=15.52$ & $H_{O}$ Diterima \\
\hline$\mu_{13}=\mu_{23}$ & 2.04 & $(8)(1.94)=15.52$ & $H_{o}$ Diterima \\
\hline$\mu_{13}=\mu 33$ & 22.43 & $(8)(1.94)=15.52$ & $H_{o}$ Ditolak \\
\hline$\mu_{23}=\mu_{33}$ & 9.83 & $(8)(1.94)=15.52$ & $H_{O}$ Diterima \\
\hline$\mu_{11}=\mu_{12}$ & 11.12 & $(8)(1.94)=15.52$ & $H_{O}$ Diterima \\
\hline$\mu_{11}=\mu_{13}$ & 12.26 & $(8)(1.94)=15.52$ & $H_{O}$ Diterima \\
\hline$\mu_{12}=\mu_{13}$ & 0.07 & $(8)(1.94)=15.52$ & $H_{O}$ Diterima \\
\hline$\mu_{21}=\mu_{22}$ & 0.26 & $(8)(1.94)=15.52$ & $H_{O}$ Diterima \\
\hline$\mu_{21}=\mu_{23}$ & 1.59 & $(8)(1.94)=15.52$ & $H_{O}$ Diterima \\
\hline$\mu_{22}=\mu_{23}$ & 0.62 & (8) $(1.94)=15.52$ & $H_{O}$ Diterima \\
\hline$\mu_{31}=\mu_{32}$ & 5.38 & $(8)(1.94)=15.52$ & $H_{o}$ Diterima \\
\hline$\mu_{31}=\mu_{33}$ & 24.54 & $(8)(1.94)=15.52$ & $H_{O}$ Ditolak \\
\hline$\mu_{32}=\mu 33$ & 12.05 & $(8)(1.94)=15.52$ & $H_{o}$ Diterima \\
\hline
\end{tabular}


Berdasarkan hasil uji komparasi rerata antar sel pada Tabel 9 tersebut, dapat disimpulkan bahwa hasil uji komparasi ganda antar sel pada baris dan kolom yang sama, diperoleh hasil bahwa: (1) pada $H_{0}: \mu_{11}=\mu_{21}, H_{0}: \mu_{11}=\mu_{31}$, dan $H_{0}: \mu_{21}=\mu_{31}$, keputusan ujinya $H_{0}$ diterima. Ini berarti pada kemampuan penalaran matematis tinggi, model pembelajaran TGT, NHT dan konvensional memberikan prestasi belajar yang sama baik, (2) pada $H_{0}: \mu_{12}=\mu_{22}$, $H_{0}: \mu_{12}=\mu_{32}$, dan $H 0: \mu_{22}=\mu_{32}$, keputusan ujinya $H_{0}$ diterima. Ini berarti pada kemampuan penalaran matematis sedang, model pembelajaran TGT, NHT dan konvensional memberikan prestasi belajar yang sama baik, (3) pada $H 0: \mu_{13}=\mu_{23}$ dan $H_{0}: \mu_{23}=\mu_{33}$, keputusan ujinya $H_{0}$ diterima. Ini berarti pada kemampuan penalaran matematis rendah, model pembelajaran TGT, NHT, dan konvensional memberikan prestasi belajar yang sama baik, dan (4) pada $H_{0}$ : $\mu_{13}=\mu_{33}$, keputusan ujinya $H_{0}$ ditolak. Ini berarti pada kemampuan penalaran matematis rendah, model pembelajaran TGT memberikan prestasi belajar yang lebih baik dari model pembelajaran konvensonal, karena dengan melihat rerata masing-masing sel pada model pembelajaran TGT sebesar 63.66, sedangkan pada model pembelajaran konvensonal sebesar 46.84, yang artinya rerata model pembelajaran TGT lebih besar dari rerata model pembelajaran konvensonal, (5) pada $H_{0}: \mu_{11}=\mu_{12}, H_{0}: \mu_{11}=\mu_{31}$, dan $H_{0}: \mu_{12}=\mu_{13}$, menghasilakan keputusan ujinya $H_{0}$ diterima. Ini berarti pada model pembelajaran TGT, siswa dengan kemampuan penalaran matematis tinggi, sedang dan rendah mempunyai prestasi belajar yang sama baik, (6) pada $H_{0}: \mu_{21}=\mu_{22}, H_{0}: \mu_{21}=\mu_{23}$, dan $H_{0}: \mu_{22}=\mu_{23}$, dengan demikian, maka hasilnya dinyatakan bahwa keputusan ujinya $H_{0}$ diterima. Ini berarti pada model pembelajaran NHT, siswa dengan kemampuan penalaran matematis tinggi, sedang, dan rendah mempunyai prestasi belajar sama baik, (7) pada $H_{0}: \mu_{31}=\mu_{32}$ dan $H_{0}: \mu_{32}=\mu_{33}$, keputusan ujinya $H_{0}$ diterima. Ini berarti pada model pembelajaran konvensonal, siswa dengan kemampuan penalaran matematis tinggi mempunyai prestasi belajar sama dengan siswa yang berkemampuan penalaran matematis sedang, dan siswa dengan kemampuan penalaran matematis sedang mempunyai prestasi belajar sama dengan siswa yang berkemampuan penalaran matematis rendah, (8)bpada $H_{0}: \mu_{31}=\mu_{33}$, keputusan ujinya $H_{0}$ ditolak. Ini berarti pada model pembelajaran langsung, siswa dengan kemampuan penalaran matematis tinggi mempunyai prestasi belajar yang lebih baik dari siswa dengan kemampuan penalaran matematis rendah, karena dengan melihat rerata masing-masing sel pada siswa dengan kemampuan penalaran matematis tinggi sebesar 67.78, Kemudian siswa yang berkemampuan penalaran matematis rendah atau kecil yaitu sebesar 46.84 , ini berarti rerata siswa yang memiliki kemampuan penalaran matematis tinggi lebih besar daripada hasil rerata siswa dengan kemampuan penalaran rendah.

Hasil dari penelitian ini telah sesuai dengan hipotesis pertama bahwa dibandingkan model pembelajaran TGT dan NHT, yang lbih baik adalah model pembelajaran TGT. kemudian untuk Model pembelajaran NHT prestasi belajarnya lebih baik daripada model pembelajaran langsung. Kemudian hasil penelitian ini juga sesuai dengan hipotesis kedua yaitu dibandingkan siswa dengan kemampuan penalaran matematis sedang dan rendah, prestasi belajar yang lebih baik yaitu yang berkemampuan penalaran matematis rendah. Sedangkan hasil penelitian lain sesuai dengan hipotesis ketiga yaitu terdapat interaksi antara 
model pembelajaran dan kemampuan penalaran matematis siswa terhadap prestasi belajar siswa, namun tidak semuanya sesuai dengan hipotesis ketiga.

Pada penelitian sebelumnya untuk penggunaan model TGT dan model NHT memberikan pengaruh yang positif, dengan menghasilkan tunjauan bahwa model TGT lebih efektif dibandingkan dengan model NHT terhadap kemampuan penalaran matematis siswa. Begitu juga dengan hasil penelitian ini, di dapatkan bahwa berdasarkan hasil penelitian dan pembahasan model TGT lebih baik dan lebih efektif dibandingkan dengan model NHT. Artinya dengan menggunakan model TGT dapat meningkatkan hasil belajar siswa yang lebih baik ditunjukkan dengan hasil prestasi matematika yang baik juga terhadap kemampuan penalaran matematis siswa (Ing, 2014; Shin, 2015; Schenke et al., 2016; Shanley, 2016; Harwell et al., 2016; Goldstone et al., 2017; Little et al., 2017)

\section{SIMPULAN DAN SARAN}

Berdasarkan hasil analisis dan pengolahan datayang didukung dengan landasan teori serta mengacu pada tujuan penelitian, maka dapat disimpulkan bahwa: terdapat pengaruh model pembelajaran TGT dan NHT terhadap kemampuan penalaran matematis siswa; prestasi matematika dengan model TGT lebih baik dibandingkan prestasi matematika dengan model pembelajaran NHT dan pembelajaran Konvensional; dan siswa dengan kemampuan penalaran matematis tinggi memiliki prestasi belajar yang lebih baik dibandingkan dengan kemampuan penalaran matematis sedang dan rendah. Berdasarkan kesimpulan di atas terdapat beberapa saran diantaranya: untuk penelitian selanjutnya dapat mencari modelmodel pembelajaran lain yang lebih berpengaruh terhadap kemampuan penalaran matematis siswa dan mencoba menggunakan model yang sama ataupun model-model pembelajaran lain dengan mencari pengaruh lain maupun menambah tinjauan penelitian terhadap kemampuan afektif siswa. Semoga penelitian ini dapat bermanfaat dan menjadi sumber rujukan ataupun referensi penelitian selanjutnya.

\section{DAFTAR PUSTAKA}

A.S. Ruslan, d. S. (2013). Pengaruh Pemberian Soal Open Ended Terhadap Kemampuan Penalaran Matematis Siswa. Jurnal Kreano , 4 (2), 138-150.

Agustina, R. L. (2015). Upaya Meningkatkan Hasil Belajar IPA Siswa Kelas IV Menggunakan Model STAD dan NHT. Journal of EST , 1 (3), 31-38.

Alifiani, A. (2017). Penerapan Model Pembelajaran NHT-TGT untuk Meningkatkan Motivasi dan Pemahaman Konsep Materi Matematika SMA. Jurnal Riset Pendidikan Matematika , 4 (1), 11-20.

Anggoro, R. P. (2015). Pengaruh Pembelajaran Kooperatif Tipe NHT dan TAI dengan Pendekatan Kontekstual terhadap Partisipasi dan Prestasi Belajar Matematika. Pythagoras: Jurnal Pendidikan Matematika , 10 (1), 71-79.

Aryani, W. D. (2015). Implementasi Teams Games Tournaments (TGT) Berbantuan Media Kartu 4-1 Untuk Meningkatkan Keterampilan Sosial dan Hasil Belajar IPS Peserta 
Didik Kelas IX F Di SMPN 1 Kandeman Batang 2014/2015. Jurnal Forum Ilmu Sosial , 42 (1), 81-105.

Boxtel, J. M. (2016). A Self-Instruction Strategy for Twice-Exceptional Learners Struggling With Common Core Mathematics. Teaching Exceptional Children , 67-73.

Dargito. (2014). Metode Pembelajaran TGT Dengan Bermain Ular Tangga (UTANG) Untuk Meningkatkan Hasil Belajar PPKN Materi Pelanggaran HAM Pada Siswa Kelas X SMA Negeri 1 Semarang Tahun Pelajaran 2013/2014. Jurnal Forum Ilmu Sosial , 41 (2), 245-256.

Farida, N. (2014). Pengaruh Sikap Kreatif Terhadap Prestasi Belajar Matematika. Jurnal Pendidikan Matematika , 3 (2), 10-15.

Fausan, M. M. (2016). Implementation Of Numbered Head Together Strategy IN Setting STAD Model Learning. Jurnal Pendidikan Biologi Indonesia , 2 (2), 154-160.

Firdaus. (2016). Efectivity of Cooperatif Learning of NHT Type in Mathematics Learning at Senior High School. Jurnal Sainsmat, 5 (1), 94-105.

Fitrianawati, M. d. (2016). Perbandingan Keefektifan PBL Berseting TGT dan GI Ditinjau Dari Prestasi Belajar, Kemampuan Berpikir Kreatif dan Oleransi. Jurnal Riset Pendidikan Matematika , 3 (1), 55-65.

Goldstone et al. (2017). Adapting Perception, Action, and Technology for Mathematical Reasoning. Association For Psychological Science, 1-8.

Gusniawati S., E. d. (2015). Penerapan Metode Pembelajaran Kooperatif Teknik Team Games Tournament Dalam Upaya Meningkatkan Hasil Belajar Siswa Pada Mata Pelajaran Matematika Sub Materi Pokok Bilangan Bulat. Jurnal EduMa , 4 (1), 113-125.

Hadiyanti, R. K. (2012). Keefektifan Pembelajaran Kooperatif Numbered Head Together Terhadap Kemampuan Pemahaman Konsep. Unnes Journal of Mathematics Education , $1(1), 59-65$.

Handayani, A. D. (2013). Penalaran Kreatif Matematis. Jurnal Pengajaran MIPA , 18 (2), 161-166.

Hapizah. (2014). Pengembangan Instrumen Kemampuan Penalaran Matematis Mahasiswa pada Mata Kuliah Persamaan Diferensial. Jurnal Kreano , 5 (1), 73-81.

Harwell et al. (2016). A Study of the Relationship Between the ACT College Mathematics Readiness Standard and College Mathematics Achievement. Journal of Psychoeducational Assessment, 34 (3), 269-281.

Hidayati, N. (2017). Peningkatan Motivasi Belajar Mahasiswa Terhadap Prestasi Belajar Aljabar Matriks. Aksioma: Jurnal Pendidikan Matematika , 6 (1), 28-32.

Hunter, W. d. (2013). Examining the Effectiveness of Numbered Heads Together for Students With Emotional and Behavioral Disorders. Beyond Behavior , 40-45. 
Ing, M. (2014). Can Parents Influence Children's Mathematics Achievement and Persistence in STEM Careers? Journal of Career Development , 41 (2), 87-103.

Jamalong, A. (2012). Improving Students Achievments By Using Cooperatif Model Of Numbered Heads Together (NHT) At Class X Of Public Senior Hight. Jurnal Pendidikan dan Kebudayaan, 18 (4), 394-411.

Khasanah, N. (2013). Peningkatan Aktivitas dan Hasil Belaja Permasalahan Tenaga Kerja Indonesia Dengan Numbered Head Togrther (NHT). Economic Education Analysis Journal , 2 (2), 75-82.

Lanani, K. (2015). Efektivitas Pembelajaran Kooperatif Ditinjau Dari Peningkatan Kemampuan Penalaran Logis Matematis Siswa. Infinity: Jurnal Ilmiah Program Studi Matematika , 4 (2), 140-151.

Little et al. (2017). Early Opportunities to Strengthen Academic Readiness: Effects of Summer Learning on Mathematics Achievement. National Association for Gifted Children, 62 (1), 83-95.

Lovieana, L. M. (2015). Penerapan Model Pembelajaran Teams Games Tournament (TGT) Sebagai Upaya Meningkatkan Aktivitas Belajar Pada Kompetensi Dasar Memilih Jenis Penggandaan Dokumen Yang Sesuai Di SMK Nasional Pati. Economic Education Analysis Journal , 4 (1), 122-133.

Marasiwi. (2017). Penerapan Model Pembelajaran Kooperatif Tipe Numbered Heads Together (NHT) Untuk Meningkatkan Prestasi Belajar Matematika Siswa. Premiere Educandum: Jurnal Pendidikan Dasar dan Pembelajaran , 7 (1), 19-27.

Mikrayanti. (2016). Meningkatkan Kemampuan Penalaran Matematis melalui Pembelajaran Berbasis Masalah. Suska Journal of Mathematics Education , 2 (2), 97-102.

Munawaroh, S. M. (2016). Pengaruh Pembelajaran Team Games Tournament Berbantuan Crossword Puzzle Terhadap Hasil Belajar. Jurnal Inovasi Pendidikan Kimia , 10 (1), 1672-1682.

Nursyahidah, F. B. (2016). Kemampuan Penalaran Matematis Siswa SMP dalam Belajar Garis dan Sudut dengan GeoGebra. Suska Journal of Mathematics Education , 2 (1), 13-19.

Pamungkas, A. S. (2016). Pengembangan Bahan Ajar Untuk Peningkatan Kemampuan Penalaran Matematis Mahasiswa Calon Guru Matematika. JPPM , 9 (2), 177-182.

Prastiti, W. (2016). Penerapan Pembelajaran Kooperatif Tipe Numbered Heads Together (NHT) Pada Materi Gerak Parabola dan Gerak Melingkar Melalui Kegiatan Lesson Study. JPF: Jurnal Pendidikan Fisika , 15 (1), 48-58.

Purnawan, d. S. (2015). Pengaruh Metode Kooperatif TGT dan NHT Terhadap Prestasi dan Kepuasan Pembelajaran Kelistrikan Otomotif di SMK. Jurnal Pendidikan Vokasi , 5 (1), 27-41. 
Purwanto, I. M. (2012). Implementasi Permainan Monopoli Fisika Sebagai Media Pembelajaran Dalam Pembelajaran Kooperatif Tipe TGT Untuk Meningkatkan Prestasi Belajar dan Mengetahui Profil Kemampuan Berpikir Kritis Siswa SMP. Jurnal Pengajaran MIPA , 17 (1), 69-76.

Putra, H. E. (2014). Sikap Mahasiswa Bahasa Inggris Terhadap Penggunaan Teknik Team Game Tournament (TGT) Pada Mata Kuliah Reading Comprehension III. Ta'dib , 17 (2), 157-176.

R. Triastuti, A. M. (2013). Keefektifan Model CIRC Berbasis Joyful Learning Terhadap Kemampuan Penalaran Matematis Siswa SMP. Jurnal Kreano , 4 (2), 182-188.

Raharja, V. J. (2016). The Implementation Of Numbered Heads Together (NHT) Cooperatif Learning Model. Journal of Accounting and Business Education , 2 (3), 1-7.

Rianto, H. d. (2014). Pengaruh Pembelajaran Inquiry dan Problem Solving terhadap Motivasi dan Prestasi Belajar Matematika. Pythagoras: Jurnal Pendidikan Matematika , 9 (1), $1-10$.

Ridwan, M. (2017). Profil Kemampuan Penalaran Matematis Siswa Ditinjau Dari Gaya Belajar. Kalamatika: Jurnal Pendidikan Matematika , 2 (2), 193-206.

Rohmah, E. A. (2016). Pengaruh Model Pembelajaran Kooperatif Tipe Teams Games Tournament (TGT) Berbantuan Media Game Online Terhadap Pemahaman Konsep dan Penalaran Matematis Siswa. Edu Humaniora: Jurnal Pendidikan Dasar , 8 (2), 126-143.

Rosita, C. D. (2014). Kemampuan Penalaran dan Komunikasi Matematis: Apa, Mengapa, dan Bagaimana Ditingkatkan Pada Mahasiswa . Jurnal Euclid , 1 (1), 33-46.

Schenke et al. (2016). Construct Confounding Among Predictors of Mathematics Achievement. Aera Open , 2 (2), 1-16.

Setiawan, A. (2017). Pengaruh Kemampuan Analisis terhadap Prestasi Belajar Matematika Ditinjau dari Intellegent Quotion (IQ). Jurnal Matematika dan Pendidikan Matematika $, 1(1), 57-78$.

Setyowati, Y. H. (2017). Penggunaan Metode Kooperatif Model Team Games Tournament Untuk Meningkatkan Kemampuan Belajar Berhitung Perkalian dan Pembagian Siswa Kelas II. Premiere Educandum: Jurnal Pendidikan Dasar dan Pembelajaran , 7 (1), 87-94.

Shanley et al. (2017). Early Number Skills Gains and Mathematics Achievement: Intervening to Establish Successful Early Mathematics Trajectories. The Journal of Special Education, 1-12.

Shanley, L. (2016). Evaluating Longitudinal Mathematics Achievement Growth: Modeling and Measurement Considerations for Assessing Academic Progress. Educational Researcher, 20 (10), 1-11. 
Shin, M. d. (2015). A Synthesis of Mathematical and Cognitive Performances of Students With Mathematics Learning Disabilities. Journal of Learning Disabilities , 48 (1), 96112.

Shoolihah, A. (2012). Perbandingan Metode Pembelajaran Teams Games Tournament dan Numbered Heads Together Dalam Meningkatkan HAasil Belajar Siswa. Economic Education Analysis Journal , 1 (2), 1-7.

Siregar, F. A. (2012). Pengaruh Model Kooperatif Tipe NHT Terhadap Hasil Belajar Siswa Kelas VIII SMP Negeri 18 Medan. Jurnal Pendidikan Fisika , 1 (1), 33-38.

Stiawan, D. (2017). Relasi Kebiasan Belajar, Pergaulan, dan Prestasi Belajar Matematika di Lembaga Pendidikan Islam. Jurnal Penelitian , 14 (1), 13-22.

Subroto, T. d. (2015). Penggunaan Model Pembelajaran Kooperatif Tipe Teams Games Tournament (TGT) Untuk Meningkatkan Pemahaman Matematis Siswa. Jurnal Euclid , 2 (1), 146-152.

Susmiatiningsih, F. S. (2013). Upaya Peningkatan Prestasi Belajar Matematika Dengan Pembelajaran Kooperatif Tipe Teams Games Tournament (TGT) Pada Pokok Bahasan Peluang Di SMA Negeri 1 Dagangan Madiun Kelas XI IPS. (1-6, Penyunt.) Jurnal Ilmiah Pendidikan Matematika , 1 (2).

Sutoyo, M. N. (2015). Penerapan Fuzzy C-Means untuk Deteksi Dini Kemampuan Penalaran Matematis. Scientific Journal of Informatics , 2 (2), 129-136.

Suzana, A. (2017). Komparasi Keefektifan Pendekatan CTL Setting NHT dan TGT pada Materi Bangun Datar. Jurnal Riset Pendidikan Matematika , 4 (1), 21-31.

Trisnawati, d. D. (2015). Perbandingan Keefektifan Quantum Teaching dan TGT Pada Pembelajaran Matematika Ditinjau Dari Prestasi dan Motivasi. Jurnal Riset Pendidikan Matematika , 2 (2), 297-307.

Wibowo, A. (2017). The Effect of Teaching Realistic and Scientific Mathematics Approach on Students Learning Achievement, Mathematical Reasoning Ability, and Interest. Jurnal Riset Pendidikan Matematika , 4 (1), 1-10.

Widhiastuti, R. d. (2014). Teams Games Tournament (TGT) Sebagai Metode Untuk Meningkatkan Keaktifan dan Kemampuan Belajar. Jurnal Pendidikan Ekonomi Dinamika Pendidikan, 9 (1), 48-56.

Widiastuti, d. R. (2014). Pengaruh Metode Inkuiri terhadap Ketercapaian Kompetensi Dasar, Rasa Ingin Tahu, dan Kemampuan Penalaran Matematis. Pythagoras: Jurnal Pendidikan Matematika, 9 (2), 196-204.

Yenni, R. F. (2016). Penggunaan Metode Numbered Head Together (NHT) Dalam Pembelajaran Matematika. JPPM , 9 (2), 263-267.

Zaenab, S. (2016). Analisis Kemampuan Penalaran Matematis Siswa Melalui Pendekatan Problem Posing Di Kelas X IPA 1 SMA Negeri 9 Malang. Jurnal Inovasi Pembelajaran, 2 (2), 97-102. 